\title{
ESSAYS
}

\section{EXPRESSIVE MOVEMENT \& CREATIVE DANCE PRACTICE IN TIMES OF QUARANTINE: THE \#VIDLOP MOVEMENT}

\author{
PRÁTICA DE EXPRESSÃO CORPORAL EM TEMPOS DE \\ QUARENTENA: O MOVIMENTO \#VIDLOP C
}

PRÁCTICA DE EXPRESIÓN CORPORAL EN TIEMPOS DE

CUARENTENA: EL MOVIMIENTO \#VIDLOP C

otit' https://doi.org/ 10.22456/1982-8918.105802

Mar Lara-Aparicio* <marlara90.ml@gmail.com>

Daniel Mayorga-Vega** <dmayorga@ujaen.es>

Iván López-Fernández* <ivanl@uma.es>

\footnotetext{
*University of Malaga. Malaga, España.

**University of Jaen. Jaen, España.
}

\begin{abstract}
The situation created by the novel coronavirus disease has affected education worldwide, resulting in the urgent need for programs that promote physical activity at home and responsible use of internet-connected devices. This work provides a didactic proposal to perform Expressive Movement \& Creative Dance (EMCD) at home adaptable to distinct educational levels and useful as a valuable online or face-to-face education experience even when the coronavirus crisis ends. The proposal is based on the Laban Movement Analysis, the Theatre of the Oppressed, and the Lipdub. It seeks to develop students' own artistic body language, emotional intelligence, healthy physical activity and social awareness. Furthermore, it intends to promote the creation of a new social movement (\#VIDLOP) using art and popular media as empowering and democratic channels for building a better world. In conclusion, this may be a promising proposal to develop the EMCD and human awareness in challenging scenarios and distinct educational settings.
\end{abstract}

Keywords: COVID-19. Social isolation. Physical Education. Health.
Received: 27 Jul. 2020 Accepted: 01 Jan. 2021 Published: 18 Feb. 2021

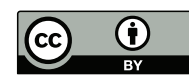

This is an article published in open access under the Creative Commons Attribution 4.0 (CC BY 4.0)

elSSN: 1982-8918 


\section{INTRODUCTION}

The Expressive Movement \& Creative Dance (EMCD) is a discipline where the person uses his/her body in an own, conscious, creative and aesthetic way to express and communicate his/her inner world (e.g., thoughts, feelings, sensations or ideas) (LARA-APARICIO; MAYORGA-VEGA; LÓPEZ-FERNÁNDEZ, 2019b). The EMCD practice gathers physical, mental, psychological and social aspects, for what it confers to the body an integral value (LARA-APARICIO; MAYORGA-VEGA; LÓPEZFERNÁNDEZ, 2019b). Due to these characteristics, this discipline is a school PE's curriculum content that is instructed in schools around the whole world (EUROPEAN COMMISSION/EACEA/EURYDICE, 2013; HARDMAN et al, 2014). Moreover, it is imparted in some university degrees and college courses, vocational schools or community projects, among other examples (PICKARD; RISNER, 2020).

As well as other kinds of physical activity practices such as football, basketball or handball, EMCD practice implies physical contact with class partners. However, many things have changed since the new coronavirus disease (COVID-19) worldwide propagation (WHO, 2020b), which has become a pandemic (WHO, 2020a). One of the policies that has been implanted is physical distancing to slow transmission and release the burden on health systems, affecting the education of $80 \%$ of children worldwide (VAN LANCKER; PAROLIN, 2020). In many countries, schools and universities have had to close their buildings and passed from a face-to-face teaching in a school classroom to a digitized teaching at home (HAMMAMI et al., 2020; VAN LANCKER; PAROLIN, 2020). These changes represent a great challenge for physical activity practice and a forecast of obesity increase, being urgent to make Physical Education a priority in schools (RUNDLE et al., 2020).

Concerning EMCD, previous research showed that physical activity professionals, despite of knowing and positively valuing EMCD's benefits, still presented confusion regarding to its planning and teaching (CONESA; ANGOSTO, 2017; LORENTE; MONTILLA; ROMERO, 2013; MONTÁVEZ, 2012). That confusion was generally caused by the feeling of not being qualified enough in the subject, what was translated into a poor teaching or, directly, into a non-teaching (CONESA; ANGOSTO, 2017; LORENTE; MONTILLA; ROMERO, 2013; MONTÁVEZ, 2012). Therefore, if the current living situation due to the COVID-19 seriously limits physical activity practice, what is happening with the EMCD instruction, if it already had teaching deficiencies before this? Because EMCD instruction is not just telling students to create a dance or to follow a YouTube Zumba class without further ado. Hence, in accordance with the EMCD's characteristics, objectives and contents, the objective of the present article is threefold: (1) to provide an EMCD didactic proposal to perform at home, adaptable to different educational levels, and useful as well as a valuable online or face-to-face education experience even when the coronavirus crisis subsides; (2) to offer a novel and promising art practice as means of expression and social movement (\#VIDLOP); and (3) to serve as an EMCD's guide for educational professionals and any person interested. 


\section{DIDACTIC PROPOSAL'S FOUNDATIONS}

\subsection{EMCD'S CHARACTERISTICS}

The EMCD is a discipline based on a spontaneous behavior that has always existed, both in ontogenetic and phylogenetic sense (STOKOE; HARF, 1987). This discipline makes the person to enter in a world that has been relegated to the oblivion due to the imposition of stereotyped daily life habits (BOSSU; CHALAGUIER, 1986). Its objective is the rediscovery (BOSSU; CHALAGUIER, 1986), the sensitization and the self-awareness (i.e., postures, attitudes, gestures and daily actions); the awareness of our need to express, communicate, create, share and interact in society; and to deepen and enrich our spontaneity and natural creativity (STOKOE; HARF, 1987).

The birth of the EMCD as a discipline is placed in the 1960s (MONTÁVEZ, 2012). However, its origin is not concrete. The influences that developed this discipline come since the middle of the $18^{\text {th }}$ century from Noverre, and continued with the influences received from Delsarte, the European gymnastics movements, the arts (LANGLADE; DE LANGLADE, 1986), the psychology, the pedagogy and the 1960s social state (VÁZQUEZ, 1989), among others. That multifaceted origin led to the EMCD to introduce itself into different study fields in the 1960s, facilitating its practice from different orientations (i.e., Social, Psychological-Therapeutic, Scenic-Artistic, Philosophical-Metaphysical and Pedagogical-Educational; RUANO; LEARRETA; BARRIOPEDRO, 2006), and appearing for the first time at the Physical Education context in France in the late 1960s (VÁZQUEZ, 1989).

The multiple origin of this discipline and the different orientations through which it can be carried out, may be at the origin of the lack of consensus in its conceptualization (MONTESINOS, 2015) and denomination (LARA-APARICIO; MAYORGA-VEGA; LÓPEZ-FERNÁNDEZ, 2019a), being still frequent the erroneous identification between the EMCD and any other kind of motor artistic-expressive activity and/or discipline (ROMERO; CHIVITE, 2013). Consequently, its research and understanding are highly relevant to be able to carry out its properly teaching and to spread worldwide its knowledge.

In order to teach EMCD, an essential aspect to know is the difference between this discipline and other motor artistic-expressive ones as can be, for instance, the Argentinian tango (OLSZEWSKI, 2008) or the Naturalistic Theater (MEYERHOLD; BEESON, 1960), among others. In this sense, EMCD does not teach specific postures, movements or techniques. On the contrary, this discipline guides the students by using different instructions in order to develop students' self-perception, self-knowledge and creativity, leading them to develop their own body language through which artistically express and communicate themselves as individuals or as group, with or without material (LARA-APARICIO; MAYORGA-VEGA; LÓPEZ-FERNÁNDEZ, 2019b). What is more, it gives the importance to the learning process and not to the final outcome (MONTESINOS, 2015). Meanwhile, other motor artistic-expressive disciplines as the ones discussed above (i.e., Argentinian tango and Naturalistic Theater), are based on learning a series of concrete steps and movements (MEYERHOLD; BEESON, 1960; OLSZEWSKI, 2008). Even though it is possible to give to these disciplines (i.e., Argentinian tango and Naturalistic Theater) a personal touch, they will always be specific 
body languages, and the final outcome the learning protagonist (LARA-APARICIO; MAYORGA-VEGA; LÓPEZ-FERNÁNDEZ, 2019b). Consequently, it is really important to begin the practice by teaching EMCD in order to get their objectives, which will prepare the students and will create a base to afterward access to other motor artisticexpressive disciplines in an originally and creatively way (MONTESINOS, 2015).

The next example from a distinct perspective could be helpful to understand the previous argument. If, when an educator is going to teach children for their very first time how to draw a house, he/she tell them exactly how they have to do it (e.g., square structure, red roof or brown rectangular door), the next times that the educator asks for it or that they draw it by themselves, what they are going to draw is the exact or really similar kind of house that the educator had taught. Nevertheless, if when an educator teach children to draw a house he/she gives them specific instructions (e.g., it has to have a door in order to people can enter or windows to let sunlight pass) but, he/she let them freedom to explore with different kinds of forms, colors or textures, for example, children will listen to themselves and will work and develop their imagination, creativity and expressivity, leading to varied and unique ways of house painting. Same happens with body language. If we teach first specific steps or movements to our students (e.g., Argentinian tango or Naturalistic Theater), we are not giving them the opportunity to develop their own body language fully (i.e., EMCD).

Therefore, body expressivity treatment and its teaching at the formal education context can not only be delegated to the practice of ballroom dances and theatre, among others (ROMERO, 2015). Otherwise, that kind of motor artistic-expressive disciplines could be used as another way of practice and slowly introduced, but just once EMCD's basic goals have been achieved (RUANO, 2004) and by paying attention to its symbolic and cultural value (COTERÓN; SÁNCHEZ, 2010).

Thus, there is not necessarily a pre-established steps' or gestures' learning in the EMCD, but the concretion of certain shared patterns of behavior which can be integrated into the person others expressive languages like speech, drawing and writing (STOKOE; HARF, 1987). The exercises have the peculiarity that, on the one hand, give very concrete premises that help to focus on a topic and, on the other hand, are open to different contributions by the classmates or the educator (MOTOS; GARCÍA, 2007; SCHINCA, 2010). Then, movement must be seen as an expressive quality and not as a mean of performing a feat because, otherwise, it would become devoid of meaning and empty (LANGLADE; DE LANGLADE, 1986).

As we have seen, any EMCD activity performed in an educational setting should have a curricular frame that details the objectives, contents, methodology and assessment.

\subsubsection{Objectives}

According to Learreta, Sierra and Ruano (2005), the ECMD's objectives are:

- to develop spontaneity and imagination;

- to respect others' productions, assuming them as a reflection of their own identity;

- to value body and movement as a depository and issuer of affectivity, emotions and feelings; 
- to accept yourself with respect and deepen into the knowledge of yourself through EMCD's dimensions (i.e., expressiveness, communication, creativity and aesthetics);

- to use body and movement to promote personal development and to improve the own quality of life;

- to recognize and use the body and its possibilities as means of artistic and cultural expression;

- to improve social skills through non-verbal communication.

\subsubsection{Contents}

Based on Learreta, Sierra and Ruano (2005) and Montávez (2012), the EMCD's contents are presented in the Chart 1 :

Chart 1 - Expressive Movement \& Creative Dance's contents.

\begin{tabular}{|c|c|c|}
\hline \multirow{2}{*}{ Dimensions } & \multicolumn{2}{|r|}{ Contents } \\
\hline & Generals & Specifics \\
\hline \multirow[t]{2}{*}{ Expressive } & $\begin{array}{c}\text { Expressive } \\
\text { alphabet }\end{array}$ & $\begin{array}{c}\text { Research and awareness of: } \\
\text { - movement depending on the body parts involved } \\
\text { - support surfaces of the bodily attitudes and movement } \\
\text { - muscle tension degree } \\
\text { - gravity feeling } \\
\text { - movement possibilities depending on spatial concepts } \\
\text { - body rhythm (inner-outer) } \\
\text { - Laban's Effort qualities } \\
\text { - body sound (vocal, non-vocal and instrumental) } \\
\text { - objects' use and experience }\end{array}$ \\
\hline & Inner world & \\
\hline \multirow{4}{*}{ Communicative } & $\begin{array}{c}\text { Communicative } \\
\text { alphabet }\end{array}$ & $\begin{array}{c}\text { - Gestural language } \\
\text { - Sound communicative components (intonation, intensity/ } \\
\text { volume, pause and speed) } \\
\text { - Gestural and sound communicative rhythm }\end{array}$ \\
\hline & Outer world & $\begin{array}{c}\text { - Body simulation of moods, ideas, feelings or situations } \\
\text { - Organization of the action with a beginning, } \\
\text { development and end } \\
\text { - Bodily symbolization } \\
\text { - Object's symbolization } \\
\text { - Presentation of oneself before others }\end{array}$ \\
\hline & Personal interaction & $\begin{array}{l}\text { - Body dialogue } \\
\text { - Synchronization } \\
\text { - Complementarity }\end{array}$ \\
\hline & $\begin{array}{l}\text { Discursive } \\
\text { exchange }\end{array}$ & \\
\hline \multirow{3}{*}{ Creative } & Creative alphabet & $\begin{array}{l}\text { - Fluidity } \\
\text { - Flexibility } \\
\text { - Originality } \\
\text { - Elaboration }\end{array}$ \\
\hline & $\begin{array}{l}\text { Bodily creative } \\
\text { techniques }\end{array}$ & $\begin{array}{l}\text { - Bodily brainstorm } \\
\text { - Body improvisation } \\
\text { - Body synectics }\end{array}$ \\
\hline & Creative process & \\
\hline
\end{tabular}


Continuation of Chart 1

\begin{tabular}{|l|l|c|}
\hline \multirow{4}{*}{ Aesthetic } & Aesthetic alphabet & $\begin{array}{c}\text { As long as allows communication: } \\
\text { - balance-unbalance } \\
\text { - composition-decomposition } \\
\text { - harmony-disharmony }\end{array}$ \\
\cline { 2 - 3 } & Aesthetic process & $\begin{array}{c}\text { - More associated with discovery than } \\
\text { with the reproduction of the current fashion } \\
\text { - An element of expression and communication }\end{array}$ \\
\cline { 2 - 3 } & Aesthetic sensitivity & \\
\hline
\end{tabular}

Source: elaborated by the authors.

\subsection{LABAN MOVEMENT ANALYSIS APPLIED TO EMCD}

According to Motos and García (2007), the movement is the base of the EMCD's practice, and it is conformed by the following components: body, space, time, energy and interrelation (Chart 2). All these components, except the interrelation, coexist during the practice, since movement is born from the body, takes shape in space, develops in time, and involves certain energy (MOTOS; GARCÍA, 2007).

Chart 2 - Expressive Movement \& Creative Dance's components.

\begin{tabular}{|c|c|c|}
\hline Component & Definition & Subcomponents-Practice \\
\hline Body & $\begin{array}{l}\text { It represents the } \\
\text { movement's background } \\
\text { fabric and it is where the } \\
\text { movement is born }\end{array}$ & $\begin{array}{l}\text { Segments (e.g., head or torso), centers (e.g., of } \\
\text { expressiveness or strength), actions (e.g., walking or } \\
\text { turning), functions (e.g., receiving weight or driving } \\
\text { movement), movements (e.g., flexion or rotation), shapes } \\
\text { (e.g., elongated or round) and postures (e.g., open or tense) }\end{array}$ \\
\hline Space & $\begin{array}{l}\text { The body defines space } \\
\text { by its mere presence } \\
\text { and evolves in it }\end{array}$ & $\begin{array}{c}\text { Directions (e.g., front or up), levels (high, medium and low), } \\
\text { paths (e.g., curved or straight), dimensions (large-small) and } \\
\text { categories (near-general) }\end{array}$ \\
\hline Time & $\begin{array}{l}\text { It manifests itself in } \\
\text { the rhythm and sets } \\
\text { the sequence of the } \\
\text { development of each } \\
\text { movement }\end{array}$ & $\begin{array}{l}\text { Metric structure (e.g., pulse or accent) and non-metric } \\
\text { structure (e.g., fast or slow) }\end{array}$ \\
\hline Energy & $\begin{array}{l}\text { Gives dynamism and } \\
\text { contrast to movement }\end{array}$ & $\begin{array}{l}\text { Time (sudden-hold), weight (heavy-light), exit (free- } \\
\text { controlled) and space (direct-indirect) }\end{array}$ \\
\hline Interrelation & From two participants & $\begin{array}{c}\text { Role played (e.g., forming pairs or doing the same), } \\
\text { relationship in the group (form-point of contact), in time } \\
\text { (e.g., unison or canon) and in space (e.g., face-to-face or } \\
\text { meeting) }\end{array}$ \\
\hline
\end{tabular}

Source: elaborated by the authors.

\subsection{THEATRE OF THE OPPRESSED}

The Theatre of the Oppressed is a theatrical method created by the Brazilian Augusto Boal, which is based on foundations as freedom, solidarity, ethics and justice (BOAL, 2012, 2013, 2014). This method uses a set of exercises, games and dramatic techniques that aim the physical and intellectual liberation of its practitioners (BOAL, 2014). The objective is to use it as an effective and democratic 
instrument to understand and search for alternatives to social, interpersonal and individual problems (BOAL, 2013).

This kind of theater is characterized by presenting a situation of oppression where the audience is not a mere spectator but, in a specific moment, they can debate and provide solutions to improve/solve the represented situation (BOAL, 2014). All actors are protagonist and spectators are also actors, or as Boal call them, spect-actors (BOAL, 2014).

\subsection{LIPDUB}

A Lipdub (also known as Lip-Dub or Lip Dub) is a one-shot and amateur music video in which a group of people (usually employees or students) create a scenography and represent it while synchronizing lips, gestures and movements with a song, and while the camera follows them through the facilities of the institution that they belong to (DÍAZ-MÉNDEZ, 2013). Its main objective is the presentation, promotion and recreation of a collective of people (DÍAZ-MÉNDEZ, 2013).

\section{EMCD'S DIDACTIC PROPOSAL}

The didactic proposal presented in this paper is based on the principles of the Laban Movement Analysis applied to EMCD (MOTOS; GARCÍA, 2007), the Theatre of the Oppressed (BOAL, 2012, 2013, 2014) and the Lipdub (DÍAZMÉNDEZ, 2013). This didactic proposal takes into account the power of social media networks (MARTIN; HUTCHINSON, 2020) and, even though it is planned for a virtual teaching, it could be easily adapted to a face-to-face teaching so, when the implemented physical distancing policies end, it could also be used. Besides, it is planned for a middle and high school cognitive development level (i.e., 11-12 years old) and above (FELDMAN, 2004). Nevertheless, it is adaptable depending on the group/class level just by softening or hardening its activities' premises.

\subsection{DESCRIPTION OF THE PROPOSAL}

The didactic proposal is divided into two parts: (1) a physical-expressive preparation; and (2) a main task named "Speaking art".

\subsubsection{Physical-expressive preparation}

This first part is shaped by three activities.

\subsubsection{Activity A: Puzzling out your body}

Explore the different facial expressions and postures that you can do. First, do it with each part of your body separately and in every possible way that you could imagine: your forehead, eyebrows, eyes, nose, mouth, head-neck, shoulders, arms, hands-fingers, chest, abdomen, back, hips, legs and feet. Then, only two parts, three, four, until ending up doing poses with the whole body and face at the same time.

Do it first without music and then while listening your favorite songs. 
Once you have done that, dress up and make up as a mime (traditional or modern, as you like the most), and take the following photos doing the facial expressions and postures that have been most striking to you from the previous practice (Figure 1).

Figure 1 - Instructions for taking the photos.

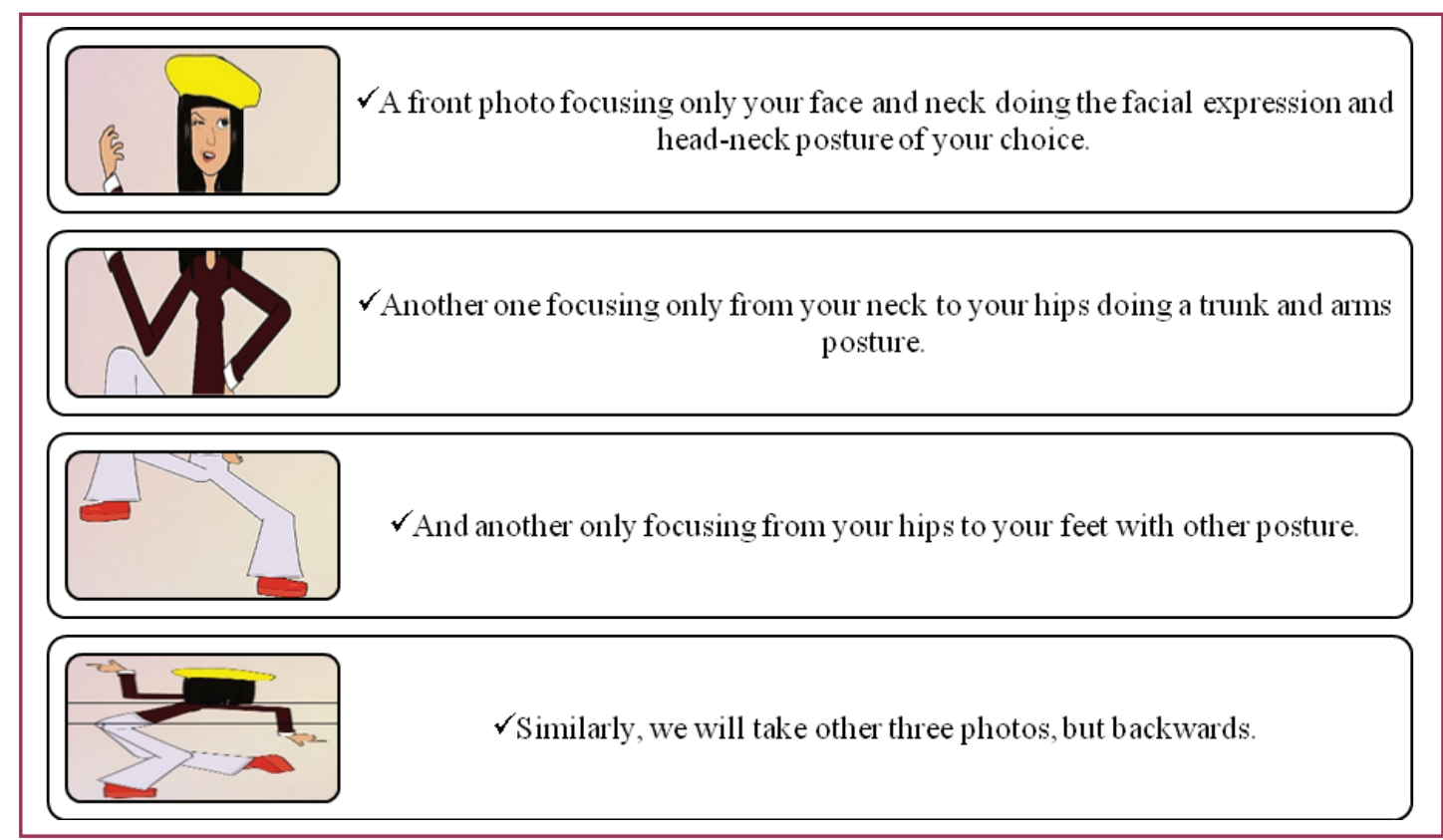

Source: elaborated by the authors.

If your arms or legs posture appear on the face-neck area photo or on another area, it is right, as long as you do not cover your face.

Now, in pairs, we will exchange our photos and we will form two full-body photos, one from the front and another from the back; but only by combining our bodyareas' photos with the ones of our partner (Figure 2). Finally, we will upload the two resulting photos to TikTok using our school subject hashtag.

Figure 2 - Example of the photo collage.

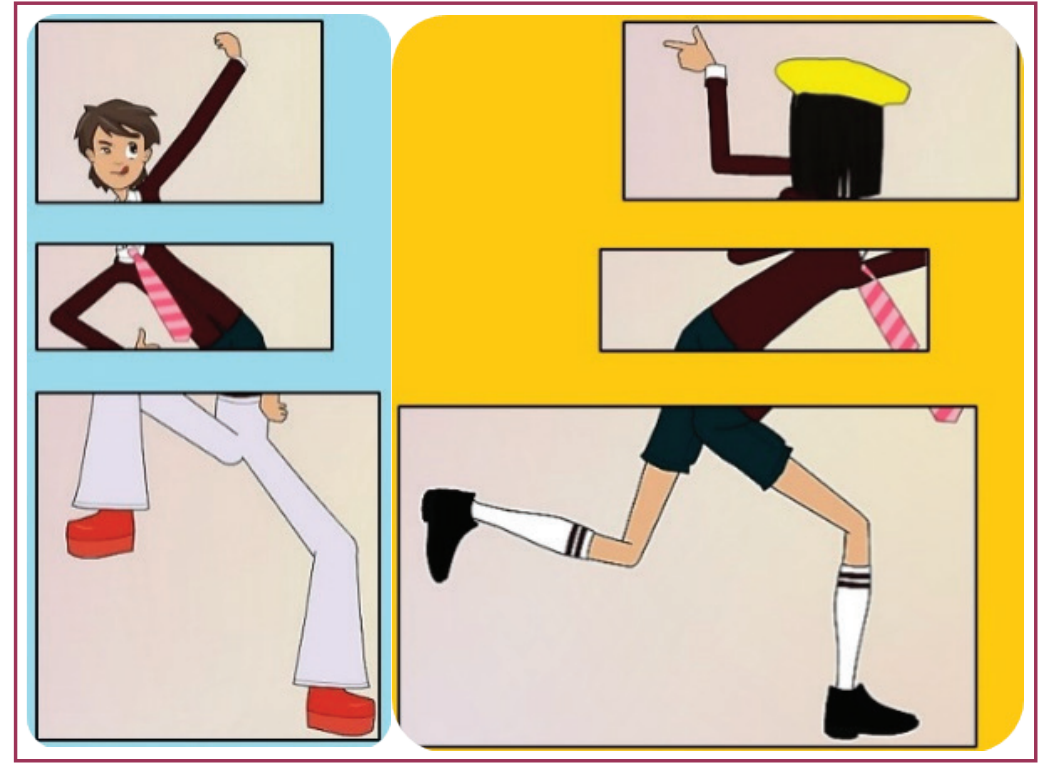

Source: elaborated by the authors. 
Adaptation examples:

- for younger students: making a card with sequential images of each body part to be used for the postural exploration, and only taking a front photo with the chosen posture (i.e., without dividing it or combining it with that of another partner);

- for older students: adding specific body parts combinations for representing animals or actions (e.g., use only eyes and chest for representing a bull), and taking and combining the Figure 2 photos dividing it into more body parts (e.g., take photos of the face, arms, hands, trunk, hip, legs and feet separately and create the collage).

\subsubsection{Activity B: Musicalizing you}

Explore the different sounds that you can make with your own body: slapping your hands together, with the palms more or less cupped, with the back of the hand on the palm, with your hand in other parts of your body, producing sounds with your hand on your mouth, with your feet on the ground, or slapping your legs between each other, for example.

Once this is done, create a 30 second song using what you have learned (i.e., body percussion; ROMERO-NARANJO, 2013) by producing sounds: loud-soft, fastslow, accelerated-decelerated, sharp-continuous or vibrated, for example. The song created must be uploaded to the school subject online site and is going to be used in the next activity.

Adaptation examples:

- for younger students: creating a card with sequential images of each body part to be used for the sound exploration, and making the song shorter (e.g., 15 seconds) and without rules;

- for older students: adding specific body parts combinations for representing animals or actions sounds (e.g., use only hands and feet for representing a teapot with boiling water), and adding specific rules to the song (e.g., must have loud, sharp and vibrate sounds).

\subsubsection{Activity C: Body-flowing}

Explore the different movements that you can do with each part of your body, first, separately, and later, by joining more and more body parts, ending up doing movements with the whole body and adding to them facial expressions. Try movements: high-low, spacious-small, sharp-continuous, strong-lightweight, fast-slow, accelerated-decelerated, forward-backward, lateral, straight-undulated, vibrated, twisted, starting with one part of the body and ending on another or controlleduncontrolled, for example.

Just like "Activity A", do it first without music and then, while listening your favorite songs.

Once this is done, in groups of four-five members, you have to create a small choreography using the percussions songs created in "Activity B" as music. Each group member must choose the ten seconds that they like the most from the body percussion song created by one of their groupmates and, with the movements explored during 
this session, choreograph those ten seconds. Each group member must begin his/ her choreography with the same posture with which the previous partner has finished its own, giving a feeling of continuity when putting together the video of each group member. Thus, for instance, the partner one of a four members group will begin his/ her choreography with the same posture with which partner number four has ended his/her own, partner two will begin with the posture with which partner one ended, partner three with the one that partner two ended and partner four with the one that partner three ended.

Additionally, two group members cannot use the same body percussion song. All group members' songs must be used. That is, partner one and two could not use the song from partner three (even if they pick different excerpts from the song), but, for instance, partner one could use partner two song, partner two could use partner three song, partner three could use partner four song and partner four could use partner one song.

Once the video is assembled, it will be uploaded to TikTok by making use of the available video editing tool and using our school subject hashtag.

Adaptation examples:

- for younger students: making a card with sequential images of each body part and the written rule (e.g., hips and lateral movements), and creating the choreography without rules;

- for older students: adding specific body parts combinations for representing animals or actions (e.g., use only head and legs for representing a snake moving), and adding more rules to the choreography (e.g., must have strong, fast and twisted movements).

\subsubsection{Main task: Speaking art}

Once students know better themselves, their body, their movement and their many possibilities, they will be ready to carry on the next activity with a broader knowledge. We will form groups of around five-six members, and each group will create a video following the steps shown in Figure 3. Of course, in case of face-toface education is not allowed because of sanitary issues, each group member will perform his/her scenes individually at home, being the final video the result of putting together the videos of each group member. This does not mean that there cannot be dialogues or interactions between the group partners, but that they must be carried out individually and will make sense once the video is assembled. 
Figure 3 - Main task's six steps.

Individually, think about the topics that affect or worry to you, your class, school, surroundings or even the world, and to which you would like to give a solution. For instance, recess boredom, bullying or unhealthy habits. You can search online for information or ask for people involved opinions. Write them down, discuss them in group and choose one in consensus (Appendix A).

Once the group have chosen a topic, you have to publish it in the school subject online site. Before publishing it, you have to check the site and be sure that your topic has not been chosen by another group yet, so each group will be working with a different topic.

Research about the roots of the chosen problem/topic (e.g., you can ask to the affected ones or search information via internet), do a group brainstorm about possible solutions and choose one (Appendix B).

Now, you are going to plan and represent that situation (that topic) and its solution by making use of different artistic techniques (e.g., drama, dance, music or fine arts), but having into account some "minimal" requirements (Figure 4).

During the representation (video creation), once you have reached to the decisive or more problematic point of the topic that you are representing, the end of that scene must be decelerating (from normal speed to super-slow) until "freeze it"; it means that you will finish that scene stopping as if you were representing a picture or a statue. Once you have "frozen" the scene, you will "rewind" the representation done by using accelerated backward movements from super-slow speed until reaching normal motion.

Once the "decelerate-stop-rewind" scene has finished, you will continue the representation but, this time, you will be representing the solution of the problem that you had been showing. Therefor, everything will keep recorded in the video, the problematic situation (topic chosen), the came back to the situation's start ("decelerate-stop-rewind"), and the solution (to the problem/topic).

Source: elaborated by the authors.

The video project "minimum" requirements are the next ones. Every group member must do these "minimums" (e.g., everyone at the same time, each one in separate scenes, two group members at the same time and the other four in separate scenes, or as your group decide it) (Figure 4): 
Figure 4 - Video project "minimum" requirements.

$\square^{-}$The video must last between a minimum of three minutes and a maximum of ten minutes.

$\square \quad$ Each group member must appear on the video the same amount of time more or less. That means, if the group is formed by five persons and the video lasts five minutes, everybody have to appear in the video around one minute; what must not be done is that one person appears two minutes and another one 30 seconds, for example.

The "decelerate-stop-rewind" fragment will last a maximum of 15 seconds.

To make use of characterization (e.g., costumes, make-up or wigs).

A song and/or a "slogan" which alludes to the solution of the chosen situation must be written. It must appear sung/rapped (on live or as lip sync) in a scene of the video. If somebody feel ashamed about singing/rapping, it is possible to make use of free mobile applications that transform the voice as, for instance, the application Voloco (VOLOCO, 2020).

In the video, each group member, at least one time, must:

make use of dance movements (of any kind or style);

make use of pantomime (to act without talking, only by using body movements,

postures and facial gestures) (ŻYWICZYŃSKI; WACEWICZ; SIBIERSKA, 2016);

make use of body percussion (as we learned on "Activity B");

make facial expression the protagonist.

make use of postures and/or movements:

high (e.g., moving on your tiptoes as if the floor burned) and low (e.g., crawling on the floor as a military);

strong (e.g., stomping on the ground) and lightweight (e.g., moving your hand as if they were floating);

spacious (e.g., stretching your body and your arms to catch the eye of someone who is far away) and small (e.g., shrinking your body as it was a ball).

Source: elaborated by the authors.

The educator should advise students to take into account that they can do more than one of those movements at the same time (e.g., stretching body and arms is a movement spacious and high); also, it is possible to do dance movements, pantomime or body percussion at the same time, for example.

Those are the "minimum" conditions to build the project, but it is very important to remember to our students that they are free to use all imaginable means in relation to body movement and postures, facial gestures, body painting, banners, room decoration, character costume and make-up, to make use of pets or other persons out of the group (but not as main characters, the main characters are them), lighting or music, among others. They are the ones who set the limit. They may also search for artistic related information as well, but using it as examples and inspiration. They must not be "copies", but dig into their imagination and CREATE, EXPRESS and COMMUNICATE their topic through the UNIQUE way in which each of them and their group can do it.

Once the video is assembled, it will be uploaded to Instagram and/or YouTube by making use of the \#VIDLOP hashtags (explained below).

Adaptation examples:

- for younger students: deleting Appendix A and B, the step 3 from Figure 3 and Figure 4;

- for older students: adding the script production and more mandatory postures/ movements (e.g., vibrated, sharp and uncontrolled). 


\subsection{CONSIDERATIONS}

Most of young people have access to smartphones and internet. For instance, about $80 \%$ of homes in Spain and Brazil have smartphones with internet access (IBGE, 2020; INE, 2019). Thereby, it is rare that a child or young person does not have access to a video camera and to internet nowadays, but the situation can occur. In this case, an alternative would be borrowing the device from a family member, a classmate or a trustworthy neighbor, for example. It is highly important to ensure that all the students have access to the necessary material before applying this didactic proposal, never leaving to anyone behind.

Another situation to consider is when a student or his/her parent is not comfortable about posting the activities results on social media networks. Of course, they do not have to, and an alternative could be sending the videos/photos to the teacher or showing them via video call.

\subsubsection{Evaluation suggestions}

As an EMCD proposal, its evaluation must have a participatory approach, be carried out continuously and evaluate the process and the product with qualitative and quantitative procedures (MOTOS; GARCÍA, 2007); giving more importance to the process than to the result (MONTESINOS, 2015). Evaluation instruments' examples are: observation records, self-evaluation reports, diary, anonymous writings or class activities (MOTOS; GARCÍA, 2007). Some examples of activities are: seated in a circle, to say something that you liked about your classmate seated at your right; to express the class' experience with the body as if it was a statue; or to paint or write on a mural your feelings at ending each session (MOTOS; GARCÍA, 2007).

Below, there are some tools for evaluating the presented didactic proposal, which the teacher can adapt to his/her class or group:

- self-assessment and peer-assessment sheets: the icons of different body parts will appear in this sheet. Individually or in pairs (in person or by video call), it must be observed and written down how many different postures, sounds or movements the person has been able to do with each of these body parts, and draw and explain the strangest one and the best one. Moreover, it could be also used a double entry table with the icons of the body parts on one axis and the movement types on the other (e.g., high-low and spacious-small);

- worksheets: the Appendix A and B, and the Figure 1 and 4 as checklists;

- diary: after each session, the participants should answer the following questions (CARBALLO, 1995; MOTOS; GARCÍA, 2007):

- Date;

- What have I learned today? (objectives);

- How have I learned it? (exercises);

- How else could we have learned it? (variants of one or more exercises done);

- What the funniest moment was? (exercise that you liked the most and why); 
- Has there been a moment in which I have not had fun or had a bad time? (exercise that you liked the least and why);

- How did I feel during the session?;

- What did it make me feel this way and what aspects of myself can I improve? (during the session I felt free/nervous... because with the exercise/my group... but I think I must/l will improve... to...);

When it is a project presentation day, it could be asked only the next questions, add the next questions to the previous ones or pick some and make a mix between both:

- How has it been the project developing process? (the group formation, the theme choice, the plot elaboration, the scenography creation, the music choice process);

- How has the essays been? (with their difficulties and satisfactions);

- How has the teamwork turned out? (conflicts and solutions, responsibilities assignment, satisfactions and thanks);

- How has the staging been?;

- What has given you the collective creation? (did you like it? why?);

- Would you have preferred to start from a text already written by an author?;

- Do you feel that the work is part of you? Why?;

- Do you want to express anything else about your experience throughout this project and its staging?;

- teacher observation record: as Carballo (1995) and Motos and García (2007) suggest, this observation tool has to assess: the student individual evolution (e.g., how he/she uses postures, gestures, movements, voice, objects, seeks and raises alternatives to a situation or movement, coordinates and relates different elements, and expresses and communicates orally and bodily), interest and participation degree, creativity and originality, behavior and respect for people and material (e.g., active listening to others and conflict resolution), and attendance. Besides that, it is possible to add information to this teacher observation record when is have been a project exhibition (e.g., the evaluation of what material and how was used for creating the scenography or the technological content).

\subsection{EXPECTED RESULTS}

In accordance with the didactic proposal's foundations described in section 2 , the activities will guide students to recognize and embrace themselves and their uniqueness through the use of bodily open-ended questions, allow them to deep into their own body and movement unexplored possibilities, develop their critical thinking and creativity, and improve their knowledge and capability of express and communicate their personality through their own artistic body language. Likewise, working in groups and in pairs will improve not only cooperation and social relationships, but also will lead them to understand aesthetics as each person choice (not as "the musts" to 
follow that have been decided by a few), and to cultivate their emotional intelligence through respecting and appreciating the others' and the own one's productions.

Although the activities carried out do not involve high-intensity physical activity, we expect to break with a sedentary lifestyle by performing fun and moderate physical activities that motivate participants to join healthy physical activity behaviors. Furthermore, we hope that the commitment that the Main task "Speaking art" and the \#VIDLOP challenge (explained below) imply, to seek a solution to a significant social problem, may translate into an increase in social awareness and desirable moral behaviors, to active and conscious use of social networks, and to comprehend art as every human being natural ability.

Additionally, it is expected that this didactic proposal strengthens student's posture and movement control, coordination, laterality, gestural language, movement possibilities depending on Laban's Effort qualities concepts, rhythm (inner-outer), the knowledge of sound possibilities (vocal, non-vocal and instrumental) and sound communicative components (intonation, intensity/volume, pause and speed), the ability to make decisions and the expressive-artistic use of diverse materials and technologies.

\section{THE \#VIDLOP MOVEMENT}

Augusto Boal exposes how aesthetic illiteracy is used by oppressors as a means of brains subliminal domination, stressing the actually absence of an aesthetic uniqueness and the need to bring to these domains too social and political struggles in search of societies without oppressors and oppressed (BOAL, 2012). He affirms that real democracy will only emerge when citizens become aware of the reality in which they live and of the possible ways of transforming it by all means (i.e., sensitive: sounds and image; and symbolic: words) (BOAL, 2012). Boal proclaims that to be human is to be artist, being not enough to consume culture, enjoy art and create ideas, but being also necessary to produce culture, to be an artist and to transform our ideas into concrete and continuous social acts (BOAL, 2012).

The presented didactic proposal is not just "another program else" with which to work the EMCD, but it goes one step further due to the foundations on which it is based. Thus, according with Boal's philosophy, this proposal uses art and popular media (social media networks) as democratic power channels to build a better future.

Consequently, the main task's resulting video of this didactic proposal will be voluntarily uploaded to Instagram and/or YouTube using the \#VIDLOP hashtag. This hashtag's origin comes from the union of two words: (1) video (VIDeo), which refers to the music videos popular tool; and (2) develop (deveLOP), which refers to the search for development towards a society without oppressors and oppressed. This hashtag will be joined by others that specify the topic/problem treated in the video, for instance, if the chosen topic is bullying, the hashtags to use would be the following: \#VIDLOP \#VIDLOPbullying. In this way, the artistic-social material created gives rise to the promotion of a population empowerment and expression movement with the \#VIDLOP hashtag use, and facilitate its search related to topics/problems 
in movement by adding the use of the specific hashtag (\#VIDLOPbullying, from the previous example).

Furthermore, it could be also interesting to organize a filming exposition and/ or a live representation of the projects so the classmates or the entire school students may watch them; to create an agreement between the schools of the neighborhood or the district for doing this project and showing the results by arranging an event together; to present the students work at the school website, at government websites related to the issue for its promotion, at the affected ones associations or groups (e.g., a \#VIDLOPdrugs project could be presented in a drugs rehabilitation center), at art galleries or exhibitions, at performing arts events or contests; or even to show it at the street for general society to see it.

\section{CONCLUSION}

This work aims to display an EMCD didactic proposal which attend the educational needs caused by the COVID-19 pandemic, as well as offer a novel and promising art practice as means of democratic expression. At the same time, it expects to serve as a guide to reinforce the physical activity professionals' qualification related to this discipline in order to improve its programming and methodological application.

Based on the principles of the Laban Movement Analysis (MOTOS; GARCÍA, 2007), the Theatre of the Oppressed (BOAL, 2012; 2013; 2014) and the Lipdub (DÍAZ-MÉNDEZ, 2013), the proposal presented follows the EMCD's characteristics, objectives and contents. The proposal considers the possibility of adaptation to different educational levels, to students' personal situations and to virtual or traditional education.

The most characteristic thing about the presented work is the creation of a new social movement, the \#VIDLOP movement. Nowadays, Americans teens, for example, spend nearly seven and a half hours per day consuming recreational screen media (i.e., not including time spent for school or homework), being the most popular activity watching videos and the least popular to create own content or doing other activities such as e-reading, for example (RIDEOUT; ROBB, 2019). Hence, the didactic proposal presented not only takes advantage of the benefits of the EMCD practice (i.e., the development of physical, mental, psychological and social aspects through the use of the body in an own, conscious, creative and aesthetic way to express and communicate thoughts, feelings, sensations or ideas), but also fosters a change of perspective towards the use of social networks and new technologies. It moves the students from a position of mere consumers and followers to a producers and independents, raising awareness about art as a natural form present in every human being and as an own tool of power and change.

It would be interesting that future work carried out an experimental study that analyze the relationship between the didactic proposal presented and physical, psychological and social outcomes observed in the participants. 


\section{REFERENCES}

BOAL, Augusto. La Estética del oprimido. Barcelona: Alba, 2012.

BOAL, Augusto. Juegos para actores y no actores. Barcelona: Alba, 2014.

BOAL, Augusto. Teatro del oprimido. Barcelona: Alba, 2013.

BOSSU, Henri; CHALAGUIER, Claude. La Expresión Corporal: Método y práctica. Barcelona: Martínez Roca, 1986.

CARBALLO, Carmen. Teatro y dramatización: didáctica de la creación colectiva. Málaga: Aljibe, 1995.

CONESA, Elena; ANGOSTO, Salvador. La expresión corporal y danza en la educación física de secundaria y bachillerato. Cuadernos de Psicología del Deporte, v. 17, n. 2, p. 111120, Jul. 2017. Available at: http://scielo.isciii.es/scielo.php?script=sci_arttext\&pid=S157884232017000200012\&lng=es\&nrm=iso\&tlng=es. Accessed on: Jul. 32020.

COTERÓN, Javier; SÁNCHEZ, Galo. Educación artística por el movimiento: La expresión corporal en Educación Física. Aula, n. 16, p. 113-134, Apr. 2010.

DÍAZ-MÉNDEZ, Monserrat. Drawing attention to institutional soft tools: the case of lipdubs. Communication\&Society/Comunicación y Sociedad, v. 26, n. 1, p. 129-148, 2013. Available at: https://dadun.unav.edu/handle/10171/35428. Accessed on: Jul. 32020.

EUROPEAN COMMISSION/EACEA/EURYDICE. Physical education and sport at school in Europe. Eurydice report. Luxembourg, 2013.

FELDMAN, David Henry. Piaget's stages: the unfinished symphony of cognitive development. New Ideas in Psychology, v. 22, n. 3, p. 175-231, 2004. DOI 10.1016/j. newideapsych.2004.11.005. Available at: https://www.sciencedirect.com/science/article/pii/ S0732118X04000327. Accessed on: Jul. 32020.

HAMMAMI, Amri et al. Physical activity and coronavirus disease 2019 (COVID-19): specific recommendations for home-based physical training. Managing Sport and Leisure, p. 1-6, Apr. 2020. DOI 10.1080/23750472.2020.1757494. Available at: https://www.tandfonline.com/ doi/abs/10.1080/23750472.2020.1757494?journalCode=rmle21. Accessed on: Dic. 52020.

HARDMAN, Ken et al. UNESCO-NWCPEA: World-wide survey of school Physical Education. París: UNESCO, 2014.

HUANG, Ronghuai et al. Guidance on flexible learning during campus closures: Ensuring course quality of higher education in COVID-19 outbreak. Beijing: Smart Learning Institute of Beijing Normal University, 2020.

IBGE. Instituto Brasileiro de Geografia e Estatística. Acesso à internet e à televisão e posse de telefone móvel celular para uso pessoal 2018. Rio de Janeiro: IBGE, 2020. Available at: https://biblioteca.ibge.gov.br/visualizacao/livros/liv101705_informativo.pdf. Accessed on: Jul. 32020.

INE. Instituto Nacional de Estadística (Spain). . Encuesta sobre equipamiento y uso de tecnologías de información y comunicación en los hogares. Notas de prensa, Oct. 16, 2019. Available at: https://www.ine.es/prensa/tich_2019.pdf. Accessed on: Jul. 32020.

LANGLADE, Alberto; DE LANGLADE, Nelly Rey. Teoría general de la gimnasia. Buenos Aires: Stadium, 1986. 
LARA-APARICIO, Mar; MAYORGA-VEGA, Daniel; LÓPEZ-FERNÁNDEZ, Iván. Análisis bibliométrico de términos en inglés sobre Expresión Corporal: resultados en Web of Science ${ }^{T M}$ desde 1900 hasta 2018. Movimento, v. 25, p. e25044, jan./dez. 2019a. DOI 10.22456/1982-8918.88722. Available at: https://seer.ufrgs.br/Movimento/article/ view/88722/53292. Accessed on: Jul. 17, 2020.

LARA-APARICIO, Mar; MAYORGA-VEGA, Daniel; LÓPEZ-FERNÁNDEZ, Iván. Expresión Corporal: Revisión bibliográfica sobre las características y orientaciones metodológicas en contextos educativos. Acción Motriz, v. 22, p. 23-34, jan./j un. 2019b. Available at: http:// www.accionmotriz.com/documentos/revistas/articulos/22_3.pdf. Accessed on: Jul. 17, 2020.

LEARRETA, Begoña; SIERRA, Miguel Ángel; RUANO, Kiki. Los contenidos de Expresión Corporal. Barcelona: Inde, 2005.

LORENTE, Eloisa; MONTILLA, María José; ROMERO, María Rosario. Grado de definición y coherencia de los programas de Expresión Corporal en las titulaciones universitarias de Educación Física. Revista de evaluación educativa, v. 2, n. 1, p. 22-39, 2013.

MARTIN, Fiona; HUTCHINSON, Jonathon. Deep Data: Analyzing power and influence in social media networks. In: HUNSINGER, Jeremy; ALLEN, Matthew; KLASTRUP, Lisbeth. Second International Handbook of Internet Research. Berlin: Springer, 2020. p. 857-877.

MEYERHOLD, Vsevolod; BEESON, Nora. From" On the Theatre". The Tulane Drama Review, v. 4, n. 4, p. 134-148, May 1960. DOI: https://doi.org/10.2307/1124884.

MONTÁVEZ, Mar. La expresión corporal en la realidad educativa. Descripción y análisis de su enseñanza como punto de referencia para la mejora de la calidad docente en los centros públicos de educación primaria de la ciudad de Córdoba. 2012. 508 f. Thesis (Doctorate) - Doctorate Program, Department of Education, University of Cordoba, Cordoba, 2012.

MONTESINOS, Diego. Efectos de un programa de expresión corporal (técnicas expresivas corporales) sobre la cantidad y calidad comunicativa en alumnado y bachillerato. 2015. 452 f. Thesis (Doctorate) - Doctorate Program, Department of Physical Activity and Sports, University of Murcia, Murcia, 2015.

MOTOS, Tomás; GARCÍA, Leopoldo. Práctica de la expresión corporal. $4^{\text {th }}$ ed. Ciudad Real: Ñaque, 2007.

OLSZEWSKI, Brandon. El cuerpo del baile: The kinetic and social fundaments of tango. Body \& society, v. 14, n. 2, p. 63-81, Jun. 2008. DOI 10.1177/1357034X08090698. Available at: https://journals.sagepub.com/doi/10.1177/1357034X08090698. Accessed on: Dic. 5, 2020.

PICKARD, Angela; RISNER, Doug. Dance, Professional Practice, and the Workplace: Challenges and Opportunities for Dance Professionals, Students, and Educators. New York: Routledge, 2020.

RIDEOUT, Victoria; ROBB, Michael. The Common Sense census: Media use by tweens and teens, 2019. San Francisco: Common Sense Media, 2019. Available at: https://www. commonsensemedia.org/sites/default/files/uploads/research/2019-census-8-to-18-keyfindings-updated.pdf. Accessed on: Jul.3 2020.

ROMERO-NARANJO, Francisco. Science \& art of body percussion: A review. Journal of human sport and exercise, v. 8, n. 2, p. 442-457. 2013. DOI 10.4100/jhse.2012.82.11. Available at: https://rua.ua.es/dspace/bitstream/10045/29740/1/jhse_Vol_8_N_II_442-457. pdf. Accessed on: Jul. 32020. 
ROMERO, María Rosario. Expresión corporal en educación física. Zaragoza: Prensas de la Universidad de Zaragoza, 2015.

ROMERO, María Rosario; CHIVITE, Miguel. Análisis de la presencia social de la Expresión Corporal. EC y Universidad. Retos, n. 24, p. 184-188, 2013. Available at: https://www. redalyc.org/pdf/3457/345732290036.pdf. Accessed on: Jul. 3, 2020.

RUANO, Kiki. La influencia de la Expresión Corporal sobre las emociones: Un estudio experimental. 2004. 445 f. Thesis (Doctorate) - Doctorate Program, Department of Physics and Facilities, Polytechnic University of Madrid, Madrid, 2004.

RUANO, María Teresa; LEARRETA, Begoña; BARRIOPEDRO, María Isabel. El valor de la emoción en Expresión Corporal desde las diferentes orientaciones. Kronos, v. 5, n. 9, p. 2433, Jan./Jun. 2006. Available at: https://abacus.universidadeuropea.es/handle/11268/3310. Accessed on: Jul. 17, 2020.

RUNDLE, Andrew et al. COVID-19-related school closings and risk of weight gain among children. Obesity, v. 28, n. 6, p. 1008-1009, Mar. 2020. DOI: https://doi.org/10.1002/ oby.22813. Available at: https://onlinelibrary.wiley.com/doi/epdf/10.1002/oby.22813. Accessed on: Jul 17, 2020.

SCHINCA, Marta. Expresión Corporal: Técnica y Expresión del Movimiento. $4^{\text {th }}$ ed. [Madrid]: Wolters Kluwer, 2010.

STOKOE, Patricia; HARF, Ruth. La expresión corporal en el jardín de infantes. Barcelona: Paidós, 1987.

VAN LANCKER, Wim; PAROLIN, Zachary. COVID-19, school closures, and child poverty: a social crisis in the making. The Lancet Public Health, v. 5, n. 5, p. e243-e244, Apr. 2020. DOI 10.1016/S2468-2667(20)30084-0. Available at: https://www.thelancet.com/action/ showPdf?pii=S2468-2667\%2820\%2930084-0. Accessed on: July 2020.

VÁZQUEZ, Benilde. La educación física en la educación básica. Madrid: Gymnos, 1989.

VOLOCO: Afinación automática de voz y armonía. Google Play, 2020. Available at: https://play.google.com/store/apps/details?id=com.jazarimusic.voloco\&hl=es. Accessed on: Jul.3, 2020.

WHO. World Health Organization. WHO Director-General's opening remarks at the media briefing on COVID-19 - 9 March 2020. Mar. 2020a. Available at: https://www.who.int/dg/ speeches/detail/who-director-general-s-opening-remarks-at-the-media-briefing-on-covid-19--9-march-2020. Accessed on: Jul. 17, 2020.

WHO. World Health Organization. WHO statement regarding cluster of pneumonia cases in Wuhan, China. Jan. 2020b. Available at: https://www.who.int/china/news/detail/09-012020-who-statement-regarding-cluster-of-pneumonia-cases-in-wuhan-china. Accessed on: Jul. 3, 2020.

ŻYWICZYŃSKI, Przemysław; WACEWICZ, Sławomir; SIBIERSKA, Marta. Defining pantomime for language evolution research. Topoi, v. 37, n. 2, p. 307-318, Aug. 2016. DOI 10.1007/s11245-016-9425-9. Available at: https://link.springer.com/article/10.1007/s11245016-9425-9. Accessed on: Jul. 17, 2020. 


\section{(S) MOVIMENTO}

\section{Appendix A - Step 1's worksheet of Figure 3}

a) topics chosen by you:

$\rightarrow$

$\rightarrow$

$\rightarrow$

$\rightarrow$

$\rightarrow$

$\rightarrow$

$\rightarrow$

b) final topic chosen in group:

$\rightarrow$

\section{Appendix B - Step 3's worksheet of Figure 3}

a) (individually) do a concept map (HUANG et al., 2020) about your group topic's triggers indicating in each section the source used to obtain the information (e.g., books, blogs, papers or televised interviews.). If you have conducted any interview, do a separate concept map for each interview indicating at the beginning the interviewee relationship with the problem (e.g., PE teacher from the X's high school if your group topic is unhealthy habits).

b) (in group) match each group member information about the problem causes obtained in the previous step (a) by building a circle map (HUANG et al., 2020) and use it to do a brainstorm to reach to the solution/s considered the best to solve the problem.

c) final solution/s chosen in group: 
Resumo: A situação causada pela nova doença do coronavírus afetou a educação em todo o mundo, sendo urgente a aplicação de programas que promovam a atividade física em casa e o uso responsável de dispositivos conectados à internet. O presente trabalho apresenta uma proposta didática de Expressão Corporal (EC) para a sua prática desde casa, adaptável a diferentes níveis educacionais, e útil também como uma valiosa experiência educacional on-line ou presencial mesmo quando a crise do coronavírus acabe. Esta proposta baseia-se na Análise Laban de Movimento, no Teatro do Oprimido e no Lipdub. Procura desenvolver a linguagem corporal artística própria, a inteligência emocional, comportamentos saudáveis de atividade física e a consciência social dos alunos; e promover a criação de um novo movimento social (\#VIDLOP), usando a arte e a mídia popular como canais democráticos e de poder para construir um mundo melhor. Em conclusão, esta pode ser uma proposta promissora para o desenvolvimento da EC e da consciência humana em cenários desafiadores e em diferentes ambientes educacionais.

Palavras chave: COVID-19. Isolamento social. Educação Física. Saúde.

Resumen: La situación provocada por la nueva enfermedad del coronavirus ha afectado a la educación en todo el mundo, por lo que es urgente la aplicación de programas que promuevan la actividad física en el hogar y el uso responsable de dispositivos conectados a internet. El presente trabajo presenta una propuesta didáctica de Expresión Corporal (EC) para practicar desde casa, adaptable a diferentes niveles educativos, y útil también como una valiosa experiencia educativa online o presencial, incluso cuando la crisis del coronavirus acabe. Esta propuesta se basa en el Análisis del Movimiento de Laban, en el Teatro del Oprimido y en el Lipdub. Busca desarrollar el lenguaje corporal artístico propio, la inteligencia emocional, comportamientos saludables de actividad física y la conciencia social de los alumnos, además de promover la creación de un nuevo movimiento social (\#VIDLOP), utilizando arte y medios de comunicación populares como canales democráticos y de poder para construir un mundo mejor. En conclusión, esta puede ser una propuesta prometedora para el desarrollo de la EC y la conciencia humana en escenarios desafiantes y en diferentes entornos educativos.

Palabras clave: COVID-19. Aislamiento social. Educación Física. Salud. 


\section{USE LICENSE}

This article is published for open access under the Creative Commons International Attributions 4.0 (CC BY 4.0) license, which allows use, distribution, and reproduction in any medium, provided that the original work is properly cited. More information at: http://creativecommons.org/licenses/by/4.0

\section{CONFLICT OF INTERESTS}

The authors have declared that this work involves no conflict of interest.

\section{AUTHORS' CONTRIBUTIONS}

Mar Lara-Aparicio: Study idea and design. Data search and collection. Paper writing.

Daniel Mayorga-Vega: Study design. Paper writing.

Iván López-Fernández: Study design. Paper writing.

\section{FUNDING}

This work received Mar Lara-Aparicio is supported by a PhD grant of the Spanish Ministry of Universities (FPU18/00496). The funder had no role in the study design, data collection and analysis, decision to publish or preparation of the manuscript.

\section{HOW TO CITE}

LARA-APARICIO, Mar; MAYORGA-VEGA, Daniel; LÓPEZ-FERNÁNDEZ, Iván. Expressive Movement \& Creative Dance practice in times of quarantine: the \#VIDLOP Movement. Movimento (Porto Alegre), v. 27, e27011, Jan./Dec., 2021. Available at: https://www.seer.ufrgs.br/Movimento/article/view/105802. Accessed on [day] [abbreviated month]. [year]. DOI: https://doi.org/10.22456/1982$\underline{8918.105802}$

\section{EDITORIAL BOARD}

Alex Branco Fraga*, Elisandro Schultz Wittizorecki*, Ivone Job*, Mauro Myskiw*, Raquel da Silveira*

*Universidade Federal do Rio Grande do Sul, Escola de Educação Física, Fisioterapia e Dança, Porto Alegre, RS, Brazil 